\title{
Rapid technique of DNA-DNA in situ hybridisation on formalin fixed tissue sections using microwave irradiation
}

\author{
P J COATES, P A HALL, MURIEL G BUTLER, A J D'ARDENNE \\ From the Department of Histopathology, and Imperial Cancer Research Fund Department of Medical Oncology, \\ St Bartholomew's Hospital, London
}

SUMMARY The relative sensitivities of different protocols for detecting cytomegalovirus nucleic acid sequences in histological specimens, using a biotinylated cDNA probe, were assessed. Several commonly used pre-treatment steps were not essential, nor was the use of a highly sensitive detection system. The choice of enzyme used for proteolytic digestion of tissue seems to be important, and increasing the temperature of denaturation of tissue and probe DNA to above $100^{\circ} \mathrm{C}$ greatly increased the sensitivity of the method. Difficulties in achieving such high temperatures in a controlled manner were overcome by the use of a rapid microwave heating method that can be used routinely in laboratories. This technique detected cytomegalovirus infections in formalin fixed, paraffin processed tissue sections within a single working day.

In situ hybridisation provides a sensitive and specific method for showing virus particles, which can be used diagnostically, for the study of virally associated neoplasms, and in examining the mechanisms of viral spread. The introduction of biotinylated DNA probes $^{12}$ and the development of methods applicable to formalin fixed, paraffin processed material ${ }^{34}$ precipitated the widespread use of such techniques. The systems initially entailed several pre-treatment steps that were designed to increase the availability of tissue DNA sequences for hybridisation with the labelled probe DNA. While not individually difficult to perform, these procedures were time consuming and added to the general complexity of the methods. Simplified procedures have been reported subsequently, ${ }^{56}$ but these rely on highly sensitive methods to detect hybridised DNA.

We investigated several of the steps in in situ hybridisation to assess their contribution to the overall sensitivity of the technique. Throughout this study, we aimed to produce a simple, rapid technique capable of detecting cytomegalovirus infections in routine histology specimens.

\section{Material and methods}

Biotinylated human cytomegalovirus AD 169 was

Accepted for publication 26 March 1987 prepared as previously described. ${ }^{7}$ This probe detects cytomegalovirus (CMV) by dot blot assays and by in situ hybridisation of infected cells. The probe does not hybridise to human genomic DNA, herpes simplex virus, or varicella zoster virus. ${ }^{7}$

All of the tissues used in this study had been routinely fixed in $10 \%$ formol saline and embedded in paraffin wax and had not been specially prepared. Tissue had been removed either during surgery or at postmortem examination. Sections $(4 \mu \mathrm{m})$ were cut, attached to glass slides coated with $0.01 \%$ poly Llysine, and dried overnight at $56^{\circ} \mathrm{C}$. Whenever possible, multiwell slides ( $\mathrm{CH}$ Henley, Essex, United Kingdom) were used, as they permit the identical treatment of up to four sections simultaneously. All sections were dewaxed in xylene and endogenous peroxidase activity blocked with $1 \% \mathrm{H}_{2} \mathrm{O}_{2}$ in distilled water. The basis of our hybridisation procedure was the same as that reported by Burns et al. ${ }^{6} \mathrm{~A}$ range of probe concentrations were used in all experiments from $0 \cdot 2-1 \cdot 0 \mu \mathrm{g} / \mathrm{ml}$. Omission of biotinylated probe DNA, replacement with biotinylated bacterial plasmid DNA, and examination of non-infected tissues comprised control tissue procedures.

The following variables were examined:

STEPS TAKEN BEFORE DENATURATION

(i) Treatment with triton X 100 or hydrochloric acid, or both, before proteolytic digestion. ${ }^{34}$ 
(ii) Digestion of sections with pronase, proteinase $\mathrm{K}$, pepsin or protease type XXIV (all supplied by Sigma, United Kingdom).

(iii) Fixation in $4 \%$ paraformaldehyde following digestion. $^{3}$

DENATURATION TEMPERATURE ${ }^{8}$

Sections were digested with either pepsin $(0.5 \%$ in $0.01 \mathrm{M}$ hydrochloric acid) for 30,60 , and 90 minutes, or protease type XXIV $(0.05 \%$ in phosphate buffered saline, $\mathrm{pH} \mathrm{7.4)}$ for 10,20 , and 30 minutes. Sections were then denatured at $75^{\circ} \mathrm{C}, 85^{\circ} \mathrm{C}, 95^{\circ} \mathrm{C}$, or $100-105^{\circ} \mathrm{C}$ for eight minutes. High temperature denaturation was achieved by placing slides directly on to a hot plate at the required temperature, or by placing in a prewarmed slide tray moistened with $2 \times$ saline sodium citriate (SSC) and replacing the tray in a conventional hot air oven. Alternatively, the sections were heated by microwave irradiation, using a commercially available microwave oven (Toshiba model ER 665 ET). Initial experiments used microwave irradiation to heat directly sections covered with the hybridisation mixture, but this was ineffectual. Subsequently, we used microwaves to heat rapidly a mea- sured volume of $2 \times \mathrm{SSC}$ in a sealed tray of the type used for immunocytochemical staining (Shandon) containing up to eight slides. Trays were placed in the microwave oven operating at various power settingsto heat rapidly the $2 \times$ SSC to boiling point and so raise the temperature of the tissue sections.

DURATION OF HYBRIDISATION

Sections denatured at either $75^{\circ} \mathrm{C}$ or $100-105^{\circ} \mathrm{C}$ were के allowed to hybridise from two to 16 hours.

\section{DETECTION METHODS}

Four different detection methods based on the polymerisation of DAB in the presence of bound peroxidase were studied:

'(i) Application of goat antibiotin serum (Sigma) followed by peroxidase conjugated rabbit antigoat immunoglobulins (Dako).

(ii) The sequential treatment of hybridised sections with avidin and peroxidase conjugated biotin (Dako). (iii) Single step application of these reagents as preformed complexes (ABC).

(iv) Sequential incubation with goat antibiotin serum, biotinylated rabbit antigoat immunoglobulins (Sigma) and $\mathrm{ABC}$ detection.

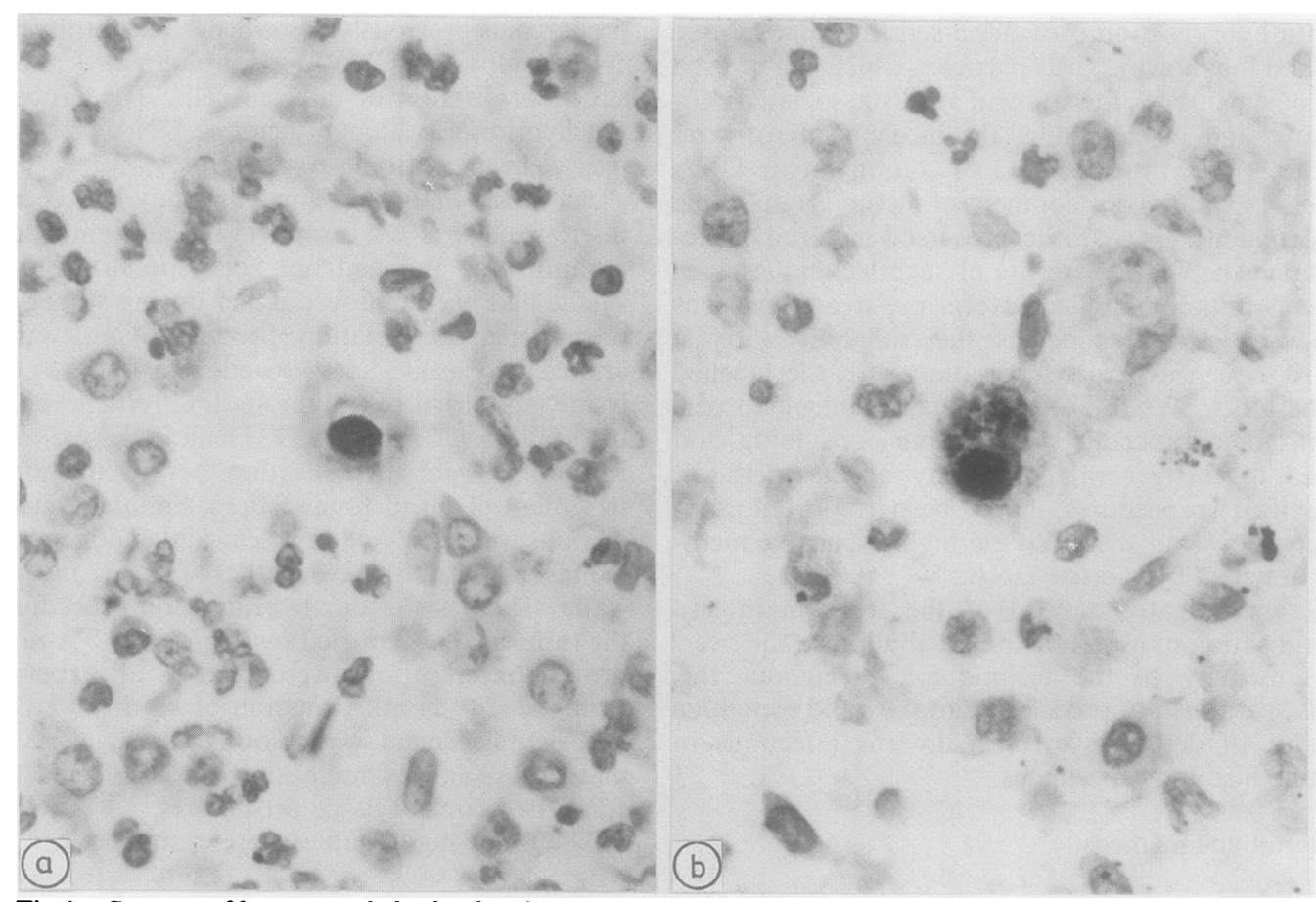

Fig 1 Sections of lung tissue hybridised with $\mathrm{HCMV} \mathrm{AD} 169(0.5 \mu \mathrm{g} / \mathrm{ml})$ for 16 hours at $42^{\circ} \mathrm{C}$ : (a) sections denatured at $75^{\circ} \mathrm{C}$; (b) section denatured by microwave irradiation. Each stained by antibiotin followed by $A B C$ detection. Intensity of nuclear staining is greater in (b) and cytoplasmic staining is also apparent. 


\section{Results}

Control sections were not stained in all cases. As a guide to the relative sensitivity of each method, test sections were assessed by the staining reactions observed at each of the different concentrations of biotinylated DNA used, and by the presence or absence of nuclear and cytoplasmic staining.

\section{STEPS TAKEN BEFORE DENATURATION}

DNA-DNA hybridisation could be reliably achieved following digestion with pepsin or protease, type XXIV, using the indirect immunoperoxidase method of detection, and probe concentrations of $0.5 \mu \mathrm{g} / \mathrm{ml}$ or higher. Hybridisation was not detectable under these conditions following treatment with pronase or proteinase $\mathrm{K}$. The use of triton X 100 or hydrochloric acid did not increase the sensitivity of our method. Fixation of sections following proteolytic digestion decreased the sensitivity of the procedure.

\section{DENATURATION TEMPERATURE}

Increasing the temperature of denaturation of probe and tissue DNA from $75^{\circ} \mathrm{C}$ to $95^{\circ} \mathrm{C}$ did not appreciably increase the sensitivity of our method. In contrast, at temperatures above $100^{\circ} \mathrm{C}$, a great improvement in staining intensity was noted (fig 1) and a probe concentration of $0.2 \mu \mathrm{g} / \mathrm{ml}$ could be used to obtain a positive showing of infected cells (table 1). Additionally, such a high denaturation temperature allowed the digestion times to be reduced by one third of the normal optimal detection time. Our initial attempts at achieving high temperature denaturation were hampered by the difficulty of controlling the temperature of a hot air oven, which inevitably cools when opened to place slides in it, considerable lifting of sections, and poor morphology of hybridised tissues when using a hot plate. These difficulties were avoided by using microwave irradiation to heat rapidly the sections from room temperature in a moist atmosphere.
DURATION OF HYBRIDISATION

Importantly, we found that infected cells could be identified following high temperature denaturation after only two hours of hybridisation (fig 2 ).

\section{DETECTION METHODS}

The use of antibiotin serum followed by peroxidase labelled antigoat is easily sufficient to detect viral particles in infected cells. The application of biotinylated antigoat serum followed by ABC detection resulted in an appreciable increase in staining intensity (table 1). Application of biotin and avdin reagents, either sequential or combined, however, was less sensitive than either of these two methods.

\section{Discussion}

Methods of in situ hybridisation have improved since their introduction in $1969 .{ }^{9}$ The application of these methods to detect high copy number sequences of DNA in paraffin embedded tissue has been used in several investigations of viral infections, including showing the presence of CMV. ${ }^{1011}$ Recent reports have discussed some of the methods and described simplified hybridisation protocols. ${ }^{68}$ The sensitivity of in situ hybridisation protocols is defined by the number of copies of nucleic acid which can be detected by the technique. In the present situation this is unknown and so the sensitivity of our technique cannot be defined in absolute terms. Guides to relative sensitivity, however, are given by the amount of biotinylated probe required to produce a positive result. This form of assessment is analagous to that commonly used in immunocytochemical analysis, where the concentration of primary antiserum required to produce a positive reaction is used to assess sensitivity. Additionally, the subjective grading of the intensity of reaction product observed at a given probe concentration provides information regarding the relative efficiency of the method.

A prerequisite of all published methods of in situ

Table 1 Effect of increased denaturation temperature and different detection methods on relative sensitivity of in situ hybridisation

\begin{tabular}{|c|c|c|c|c|c|c|}
\hline & \multicolumn{6}{|c|}{ Detection method } \\
\hline & \multicolumn{3}{|c|}{ Indirect immunoperoxidase } & \multicolumn{3}{|c|}{ Indirect $A B C$} \\
\hline & $0 \cdot 2^{*}$ & 0.5 & $1 \cdot 0$ & $0 \cdot 2$ & $0 \cdot 5$ & $1 \cdot 0$ \\
\hline $75^{\circ} \mathrm{C}$ & $+1-$ & + & ++ & + & ++ & +++ \\
\hline Microwave & ++ & +++ & +++ & +++ & +++ & +++ \\
\hline
\end{tabular}

*Values are the concentration of biotinylated HCMV AD 169 used in each experiment $(\mu \mathrm{g} / \mathrm{ml})$.

$+/-$, equivocal staining; + , weak staining; ++ , moderate staining; +++ , strong staining. 


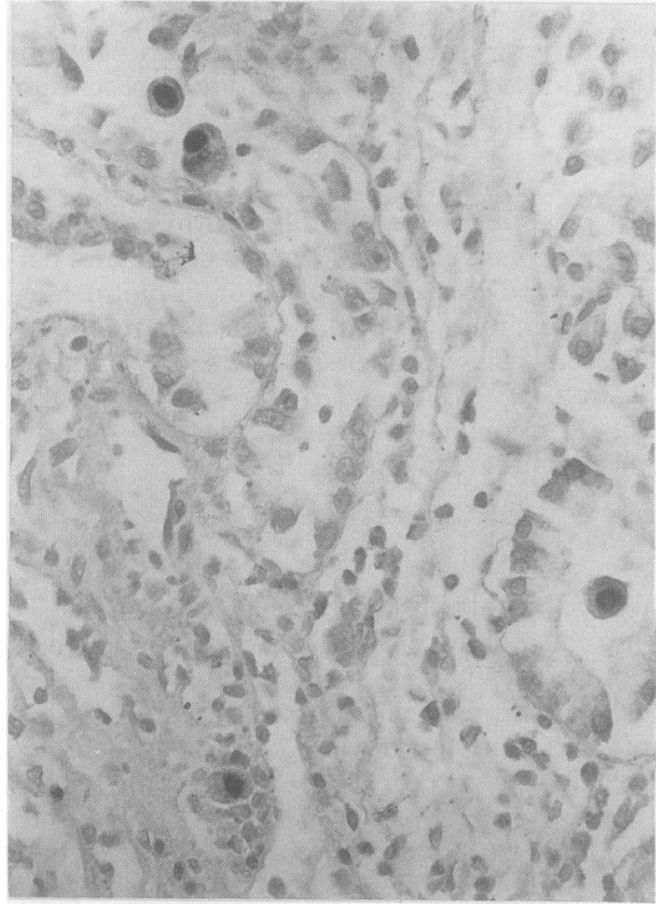

Fig 2 Sections of oesophageal mucosa hybridised with HCMV AD $169(1.0 \mu \mathrm{g} / \mathrm{ml})$ for two hours following high temperature denaturation. (Stained by antibiotin followed by $A B C$ detection.) hybridisation on formalin fixed, paraffin processed material is the proteolytic digestion step before probe DNA is applied. Enzymes commonly used include pronase 381011 and proteinase $\mathrm{K}^{4}$ which gave poor results in our hands when compared with either pepsin or protease, type XXIV, a finding in agreement with a previous report. ${ }^{6}$ This can be partly explained by the different sources of enzyme and forms of pronase used-Sigma supply pronase E, whereas others have used pronase $\mathrm{B}$ - and by the storage protocols used. $^{3}$

Of particular interest to us was the observation that increasing the denaturation temperature of tissue DNA improves subsequent hybridisation efficiency. ${ }^{8}$ This is based on the need to overcome the effects of formalin fixation by forcing the complementary strands of DNA apart. ${ }^{8}$ We confirmed this observation, but encountered difficulties in either controlling the temperature in a conventional hot air oven, or noticed severe loss of section retention and poor morphology when using a hot plate. Poor morphology was presumed to be due to drying of sections resulting from evaporation of reagents during the denaturation step. The use of microwave irradiation provides a simple and rapid method of attaining high temperature denaturation, while retaining section adhesion and adequate morphology. This technique uses rapid heating of $2 \times \operatorname{SSC}(25 \mathrm{ml})$, which boils within 25 seconds in a sealed container. Slides are thus heated in a moist atmosphere at a defined tem-

Table 2 Method of in situ hybridisation using high temperature denaturation of tissue DNA sequences

1 Dewax sections, rehydrate, and block endogenous peroxidase activity

2a Digest in $0.5 \%$ pepsin in $0.01 \mathrm{M}$ hydrochloric acid, 30 minutes, $37^{\circ} \mathrm{C}$

$O R$

$2 \mathrm{~b}$ Digest in $0.5 \%$ protease, type XXIV* in phosphate buffered saline, 15 minutes, $37^{\circ} \mathrm{C}$

3 Wash in distilled water, dehydrate in alcohol, and air dry

4 Add biotinylated probe cDNA $(0 \cdot 2-1 \mu \mathrm{g} / \mathrm{ml}$ in hybridisation medium). Cover sections with a glass coverslip

5 Place in sealed slide tray containing absorbent paper and $25 \mathrm{ml} 2 \times$ SSC. Heat in microwave oven at a moderate setting (number 5 on the Toshiba ER 665 ET) for one minute, followed by a low setting (number 1) on the Toshiba ER 665 ET) for seven minutes Transfer to $42^{\circ} \mathrm{C}$ oven for two to 16 hours

Wash coverslips off with $2 \times$ SSC

Wash in $0.1 \times \mathrm{SSC}, 42^{\circ} \mathrm{C}, 10$ minutes and $2 \times \mathrm{SSC}$, room temperature, five minutes

Rinse in PBSA (PBS with $3 \%$ bovine serum albumin)

Goat antibiotin, $10 \mu \mathrm{g} / \mathrm{ml}$ in PBSA, 30 minutes, room temperature

Wash in PBSA, $3 \times 10$ minutes

Peroxidase conjugated antigoat, $1 / 30,30$ minutes

Biotinylated rabbit antigoat, 1/200, 30 minutes; PBS, $3 \times 10$ minutes; $A B C, 30$ minutes

Wash in PBS, $3 \times 10$ minutes

Reveal labelled sites with $0.05 \%, \mathrm{DAB} / 0.006 \% \mathrm{H} 202(\mathrm{v} / \mathrm{v}), 10$ minutes

Counterstain, dehydrate, and mount in resin

Solutions

$1 \times \mathrm{SSC}=0.15 \mathrm{M} \mathrm{NaCl}, 0.015 \mathrm{M}$ sodium citrate: $\mathrm{pH} 7.0$

PBS $=0.05 \mathrm{M}$ phosphate buffered saline, $\mathrm{pH} 7.4$.

Hybridisation medium $=50 \%$ formamide (Sigma); $10 \%$ dextran sulphate (BDH, UK); $2 \times \mathrm{SSC} ; 0.2 \mathrm{mM}$ tris-HCl/0.4mM, pH 7.4; edetic

acid $20 \mu \mathrm{g} / \mathrm{ml}$ sheared herring sperm DNA (Sigma).

*Protease type XXIV was marketed as protease type VII. 
perature, given by the boiling point of the solution used $\left(104^{\circ} \mathrm{C}\right.$ in this case). Since prewarming of slide trays is not required, this method facilitates the processing of large numbers of sections.

Using this method, we observed a pronounced increase in the staining reactions observed, with the demonstration of cytoplasmic as well as nuclear viral nucleic acids in some cases (fig 1). The technique described in table 2 is versatile, as the hybridisatior. time and the detection method can be varied to suit the needs of a particular laboratory:

We are grateful to PD Griffiths for supplying biotinylated HCMV AD 169; to Dakopatts UK Ltd for the gift of the $A B C$ reagents; and to Toshiba UK for the loan of a microwave oven. PJC was supported by a grant from the Cancer Research Committee of St Bartholomew's Hospital. PAH is an ICRF Research Fellow and AJd'A is supported in part by the ICRF.

\section{References}

1 Langer PA, Waldrop AA, Ward DC. Enzymatic synthesis of biotin-labelled polynucleotides: Novel nucleic acid affinity probes. Proc Natl Acad Sci (USA) 1981:78:6633-7.

2 Singer RH, Ward D. Actin gene expression visualized in chicken muscle tissue culture by using in situ hybridization with a biotinated nucleotide analog. Proc Natl Acad Sci (USA) 1982;79:7331-5

3 Brigati DJ, Myerson D, Leary JL. et al. Detection of viral genomes in cultured cells and paraffin-embedded tissue sec- tions using biotin-labelled hybridization probes. Virology 1983;126:32-50.

4 Blum H, Haase A, Vyas G. Molecular pathogenesis of hepatitis B virus infection: simultaneous detection of viral DNA and antigens in paraffin-embedded liver sections. Lancet 1984;ii:771-5.

5 McDougall JK, Myerson D, Beckmann AM. Detection of viral DNA and RNA by in situ hybridization. J Histochem Cytochem 1986;34:33-8.

6 Burns J. Redfern DRM, Esiri MM, McGee JO'D. Human and viral gene detection in routine paraffin embedded tissue by in situ hybridisation with biotinylated probes: viral localisation in herpes encephalitis. J Clin Pathol 1986;39:1066-73.

7 McKeating JA, Al-Nakib W, Greenaway PJ. Griffiths PD. Detection of cytomegalovirus by DNA-DNA hybridization employing probes labelled with 32-phosphorus or biotin. $J$ Virol Methods 1985;11:207-16.

8 Unger ER. Budgeon LR, Myerson D, Brigati DJ. Viral diagnosis by in situ hybridization. Description of a rapid simplified colorimetric method. Am J Surg Pathol 1986;10:1-8.

9 Gall JG, Pardue ML. Formation and detection of RNA-DNA hybrid molecules in cytological preparations. Proc Natl Acad Sci (USA) 1969;63:378-83.

10 Myerson D, Hackman RC, Nelson JA, Ward DC, McDougall JK. Widespread presence of histologically occult cytomegalovirus. Hum Pathol 1984;15:430-9.

11 Löning T, Milde K, Foss H-D. In situ hybridization for the detection of cytomegalovirus (CMV) infection. Application of biotinylated CMV-DNA probes on paraffin-embedded specimens. Virchows Arch (Pathol Anat) 1986;409:777-90.

Requests for reprints to: Dr PJ Coates, Department of Histopathology, St Bartholomew's Hospital, West Smithfield, London ECIA 7BE, England. 